\title{
Characterization of the Duck Plague Virus UL35 Gene
}

\author{
Ming-Sheng Cai ${ }^{a} \quad$ An-Chun Cheng ${ }^{a, b}$ Ming-Shu Wang ${ }^{a, b}$ Wan-Ping Chen ${ }^{a}$ \\ Xian Zhang $^{\text {a }}$ Shang-Xi Zheng ${ }^{a}$ Yang Pu $^{\text {a }}$ Kun-Peng Lou ${ }^{a}$ Yao Zhang ${ }^{a}$ \\ Lei Sun $^{\mathrm{a}}$ Lu-Lu Wang ${ }^{\mathrm{a}}$ De-Kang Zhu ${ }^{\mathrm{a}} \mathrm{b}$ Qi-Hui Luo ${ }^{\mathrm{b}}$ Xiao-Yue Chen ${ }^{\mathrm{a}}$ b \\ ${ }^{a}$ Avian Diseases Research Center, College of Veterinary Medicine of Sichuan Agricultural University, and \\ ${ }^{b}$ Key Laboratory of Animal Diseases and Human Health of Sichuan Province, Yaan, China
}

\section{Key Words}

Duck plague virus - Transcription kinetics - Expression

kinetics $\cdot$ Subcellular localization

\begin{abstract}
Objective: Previous study has demonstrated that the duck plague virus (DPV) UL35 gene can be expressed as a recombinant fusion protein, and the prepared antiserum has a high reactivity and specificity against the purified recombinant protein. In the present study, to elucidate the properties and functions of its encoding protein, the UL35 gene product (VP26) was identified by using the prepared rabbit polyclonal antiserum. Methods: Real-time PCR, Western blot and immunofluorescence analysis were used to determine the transcription and expression kinetics and subcellular localization of DPV VP26 in DPV-infected cells. Results: A protein of approximately $13 \mathrm{kDa}$ that reacted with the antiserum was detected in immunoblot of DPV-infected cellular lysates. Real-time PCR and Western blot analysis of DPV-infected cells showed that VP26 was produced predominantly at the late stage of infection, its production was highly dependent on viral DNA synthesis, and the UL35 gene was regulated as a late viral gene, suggesting that the gene should be categorized as $\gamma 2$ class. Additionally, analysis of the association of
\end{abstract}

DPV VP26 with purified virions revealed that VP26 was a component of extracellular mature DPV virions. Subcellular localization demonstrated that VP26 firstly localized in cytoplasm, then it transferred to the nucleus and aggregated in the punctate region of the nucleus in DPV-infected cells. Conclusion: Taken together, these results will provide a foundation for further functional analysis of the DPV UL35 gene.

Copyright $\odot 2010$ S. Karger AG, Basel

\section{Introduction}

Duck plague (DP), which is caused by the anatid herpesvirus 1, duck plague virus (DPV), is an acute and contagious herpesvirus infection of waterfowl such as duck, goose and swan. DPV can result in heavy economic losses to the commercial duck industry due to its high mortality rate and decreased duck egg production [1-6]. Since DP was found in domestic ducks in 1923 [7], more outbreaks were reported in North America [8], Canada [9], France [10] and China [11]. Although some vaccines have been developed, the disease is not completely controlled.

\section{KARGER}

Fax +41613061234 E-Mail karger@karger.ch www.karger.com
(C) 2010 S. Karger AG, Basel

0300-5526/10/0536-0408\$26.00/0

Accessible online at:

www.karger.com/int
An-Chun Cheng

Key Laboratory of Animal Disease and Human Health of Sichuan Province Avian Diseases Research Center, College of Veterinary Medicine Sichuan Agricultural University, 46, Xinkang Road, Yaan 625014 (China)

Tel./Fax +86835288 5774, E-Mail chenganchun@vip.163.com 
Currently, DPV has not yet grouped into any genus according to the Eighth International Committee on Taxonomy of Viruses [12], although it was tentatively classified to the Alphaherpesvirinae subfamily of the Herpesviridae $[13,14]$. Like other alphaherpesviruses, DPV is a large, enveloped virus with 4 structural components including a linear, double-stranded DNA genome with 64.3\% guanine-plus-cytosine $(\mathrm{G}+\mathrm{C})$ content, an icosahedral capsid, an amorphous tegument and a bilayer lipid envelope. As with many other herpesviruses, DPV can establish unapparent infection in birds that survive exposure to it, a state referred to as latency [15]. Once DPV is reactivated, it can result in an outbreak of the disease in susceptible duck farms. This makes the disease difficult to monitor and control. At present, studies of the genomic organization and nucleotide sequence of DPV lag behind other members of the herpesviridae family because most of the previous studies have focused on the epidemiology and prevention of this disease. To the best of our knowledge, the molecular structure of the genome of DPV DNA has not been published up to now [16]. During the infection cycle, many herpesvirus proteins are involved in the late step of viral maturation at the nucleocapsid, which include the UL35 protein of herpes simplex virus (HSV) [17]. With many similarities and a few differences, accumulating evidence indicates that the UL35 protein and its homologues of Alphaherpesvirus, Betaherpesvirus and Gammaherpesvirus may play similar roles in viral assembly and maturation. To date, the majority of reported DPV sequences are limited to single open reading frames, which include UL5-UL6 [16, 18 , 19], UL22-UL24 [20-22], UL25-UL30 [23], UL31-UL35 [24-27], UL44 [28, 29], UL50-UL51 [30-32], US3-US5 $[33,34]$, US8 [35], US2 and US10 [36]. However, no reports have been published concerning the characterization of transcription, expression, intracellular localization and the dependence of DPV VP26 on viral DNA synthesis.

Recently, a DPV genomic library was successfully constructed for the first time in our laboratory [37], and positive clones were stochastically selected and sequenced. Sequence analysis showed that DPV encoded several structural proteins, one of which was preliminarily identified as a viral nucleocapsid protein (VP26) encoded by the UL35 gene with a size of $354 \mathrm{bp}$ (GenBank accession No. EF643558) [38]. Simultaneouly, the fusion-expressed VP26 could be recognized by the prepared polyclonal antibody [25]. In the present study, in an effort to elucidate the properties and functions of VP26, real-time (RT) PCR, Western blot and immunofluorescence analysis were used to determine the transcription and expression kinetics, intracellular localization and the dependence of DPV VP26 on viral DNA synthesis in DPV-infected cells. Characterization of the DPV UL35 gene may provide a foundation for further study of the functions of this gene.

\section{Materials and Methods}

Virus, Cell and Reagent

DPV CHv strain, is a high-virulence field strain of DPV that was isolated and preserved in the author's laboratory. The DPV was propagated in duck embryo fibroblasts (DEFs) that were grown in Dulbecco's minimum essential medium (Gibco-BRL) supplemented with $10 \%$ fetal bovine serum (FBS; Novagen), 100 units $/ \mathrm{ml}$ penicillin, and $100 \mu \mathrm{g} / \mathrm{ml}$ streptomycin at $37^{\circ}$ throughout this study. For virus infection, Dulbecco's minimum essential medium supplemented with 2-3\% FBS was used. Commonly used reagents were offered by the Avian Diseases Research Center of Sichuan Agricultural University.

Preparation of Total RNA and RT-PCR Analysis for the

Transcription Kinetics

To examine the transcription kinetics of the DPV UL35 gene in infected cells in vitro, the procedures were carried out as previously described [31]. DEFs, grown in 6-well plates to $60-70 \%$ confluence, were either mock infected or infected with the DPV at a multiplicity of $5 \mathrm{PFU}$ per cell. After a 1-hour adsorption at $37^{\circ}$, maintenance medium supplemented with $2 \%$ FBS was added. Then, total RNA was isolated from mock-infected or DPV-infected cells at different times $(0.5,1,2,4,8,12,24,36,48,60$, and $72 \mathrm{~h}$ after infection) by using the Total RNA Isolation System (TaKaRa) according to the manufacturer's instructions and detected by $1.0 \%$ agarose gel electrophoresis. The concentration of RNA was determined by measuring A260, and the purity was checked by the A260/A280 ratio ( $>1.8$ ). A cell volume equivalent amount of total RNA $(15 \mu \mathrm{l})$ was digested by the RNase-free DNase I (TaKaRa) to eliminate contamination of chromosomal DNA before reverse transcription reaction. Based on the nucleotide sequence that we submitted to Genbank (accession No. EF643558), the forward primer (5'-TTTGGCAGAACAGATGG$3^{\prime}$ ) and reverse primer (5'-CGTATGATGCGTGGAGA-3') for PCR-based amplification of the UL35 cDNA were designed by use of the biological software Primer 5.0. $\beta$-Actin was set as the reference gene. Primers for amplification of the $\beta$-actin cDNA (nucleotide sequence obtained from Genbank) were listed as follows: 5'-CCGGGCATCGCTGACA-3' (forward primer) and 5'GGATTCATCATACTCCTGCTTGCT-3' (reverse primer). These 2 pairs of primers were synthetized by TaKaRa. According to the manufacturer's instructions (TaKaRa), $2 \mu \mathrm{g}$ of RNA was used as template and the reverse transcription reaction, which was performed in a $10-\mu$ l reaction volume to give the strand $\mathrm{CDNA}$, was carried out at $42^{\circ}$ for $50 \mathrm{~min}$, followed by inactivation of RTase at $96^{\circ}$ for $5 \mathrm{~min}$. Then, the RT-PCR assay, which was carried out on the iCycler (Bio-Rad), was performed in a volume of $25 \mu l$ containing $1.0 \mu \mathrm{l}$ of the forward primer $(10 \mathrm{pM}), 1.0 \mu \mathrm{l}$ of the reverse primer (10 pM), $1.0 \mu$ l of cDNA template, $12.5 \mu$ l of RT-PCR Master Mix SYBR Green I and $9.5 \mu$ l of deionized water (all reagents were purchased from TaKaRa). Amplification reactions were conducted with preliminary denaturation for $1 \mathrm{~min}$ at $95^{\circ}$, followed by 40 
cycles of denaturation at $95^{\circ}$ for $20 \mathrm{~s}$, annealing at $60^{\circ}$ for $30 \mathrm{~s}$ and extension at $72^{\circ}$ for $30 \mathrm{~s}$. Rigorous precautions were taken to preclude DNA contamination during RT-PCR assay. Data were obtained during the elongation period. All reactions were performed in triplicate and in at least 2 independent reactions. Using $\beta$-actin as the reference gene, the average relative content of DPV UL35 gene transcripts was calculated using the $2^{-\Delta \Delta C t}$ method $[39,40]$.

\section{Western Blot Analysis for the Expression Kinetics}

To detect the expression kinetics of the DPV UL35 gene in infected cells, Western blot analysis was performed according to the standard procedure [41] using the previously prepared rabbit anti-His6-tagged VP26 IgG [25]. DEFs were either mock infected or DPV infected as described above, and they were harvested by lowspeed centrifugation at indicated times $(2,4,8,12,24,36,48$ and $72 \mathrm{~h}$ after infection). The cells were lysed on ice for $30 \mathrm{~min}$ with an equal volume of radioimmunoprecipitation assay buffer (50 $\mathrm{mM}$ of Tris- $\mathrm{HCl}, \mathrm{pH} 7.4,150 \mathrm{~mm}$ of $\mathrm{NaCl}, 1 \%$ Triton X-100, $1 \%$ sodium deoxycholate, $0.1 \%$ SDS and $1 \mathrm{mM}$ of phenylmethylsulfonyl fluoride) [42]. After equivalent amounts of the cell lysates $(15 \mu \mathrm{l})$ had been electrophoresed on $12 \%$ SDS-PAGE, the gel was immersed in transfer buffer $(0.24 \%$ Tris- $\mathrm{HCl}, 1.153 \%$ glycine and $15 \%$ methanol, $\mathrm{pH} 8.8$ ) and electrophoretically transferred onto nitrocellulose membrane (Bio-Rad) pre-equilibrated in transfer buffer using a Mini Trans Blot electrophoretic transfer cell (Bio$\mathrm{Rad})$ at $80 \mathrm{~V}$ for $1.5 \mathrm{~h}$. The membrane was incubated in blocking buffer (5\% bovine serum albumin (BSA) in the PBS buffer) for $1 \mathrm{~h}$ at $37^{\circ}$ or overnight at $4^{\circ}$ to block the nonspecific binding protein. After 3 washes (10 min each) with $1 \times$ PBS buffer, the membrane was incubated with rabbit anti-His6-tagged VP26 IgG at a dilution of 1:100 with $1 \%$ BSA in PBS overnight at $4^{\circ}$. The membrane was then washed 3 times with $1 \times$ PBS containing $0.1 \%$ Tween-20 (PBST), and was further incubated with horseradishperoxidase-labeled goat anti-rabbit IgG (Boster) at a dilution of 1:5,000 for $1 \mathrm{~h}$ at $37^{\circ}$. The membrane was then washed 3 times with PBST and 3 times with PBS. Specific bands were detected using an enhanced chemiluminescence system according to the manufacturer's instructions (Amersham). Color development was terminated by thorough washing in distilled water. Staining with mouse anti-GAPDH (rabbit anti-glyceraldehyde-3-phosphate dehydrogease; Tiangen) antiserum diluted 1:2,000 was used as a loading control.

\section{Subcellular Localization}

The subcellular localization of DPV VP26 was analyzed by indirect immunofluorescence as described previously $[26,30,31$, 34]. In brief, DEFs, grown in a coverslip in 6-well plates, were either mock infected or DPV infected as described above. The cells were harvested at different times after infection $(2,4,8,12,24,36$, 48 and $72 \mathrm{~h}$ ) and fixed with $4 \%$ paraformaldehyde for $15 \mathrm{~min}$ at room temperature. Next, the cells were washed once with PBS and with $0.2 \%(\mathrm{v} / \mathrm{v})$ TrionX-100 in PBS for an additional $10 \mathrm{~min}$ at $25^{\circ}$ to allow permeabilization. Following several washes in PBS, the cells were air dried and blocked for $1 \mathrm{~h}$ in PBS containing 10\% BSA at $37^{\circ}$. Then, they were incubated with purified rabbit anti-His6tagged VP26 IgG specific for recombinant DPV VP26 or preimmune serum diluted 1:200 in PBS containing $0.1 \%$ BSA overnight at $4^{\circ}$, washed 3 times in PBS for $10 \mathrm{~min}$, and then treated with 1:100 dilution of fluorescein isothiocyanate (FITC)-conjugated goat anti-rabbit IgG (Millipore) in PBS containing 0.1\% BSA for
$45 \mathrm{~min}$ at $37^{\circ}$. As described by Miller et al. [43], the cell nuclei were visualized by 4',6-diamidino-2-phenylindole (DAPI) counterstaining ( $5 \mu \mathrm{g} / \mathrm{ml}$; Sigma). The coverslips with adhering cells were placed on glass slides and sealed with transparent nail polish. Fluorescent images were viewed and recorded with the BioRad MRC 1024 imaging system.

\section{Association of DPV VP26 with Purified Virions}

For exploring the association of DPV VP26 with purified virions, monolayers of DEF cells, cultured in bottles, were infected with the DPV. After $1 \mathrm{~h}$ adsorption at $37^{\circ}$, maintenance medium containing $2-3 \%$ serum was added. Then, DPV virions were harvested from the extracellular medium $48 \mathrm{~h}$ after infection. After removal of cell debris by low-speed centrifugation, virions were pelleted from the supernatant by centrifugation at $80,000 \mathrm{rpm}$ for $1 \mathrm{~h}$ at $4^{\circ}$. The virus suspension was layered onto a continuous 10 $\pm 50 \%$ sucrose gradient and centrifuged at $25,000 \mathrm{rpm}$ for $1 \mathrm{~h}$ at $4^{\circ}$. The peak virion-containing fractions were collected as described previously [44-46], diluted in PBS and pelleted again by centrifugation at $80,000 \mathrm{~g}$ for $1 \mathrm{~h}$. Purified virions were analyzed by Western blot as described above with the purified rabbit antiHis6-tagged VP26 IgG.

\section{The Dependence Analysis of DPV VP26 on Viral DNA}

Synthesis

DEFs, cultured in the 6-well plates, were infected with DPV at a multiplicity of 5 PFU per cell. After $1 \mathrm{~h}$ adsorption in the presence of $300 \mathrm{mg} / \mathrm{ml}$ of acyclovir (ACV) (Glaxo SmithKline) at $37^{\circ}$, maintenance medium containing $2-3 \%$ serum was added. Infected cells were harvested at various times $(12,24,48$ and $72 \mathrm{~h}$ after infection) and then analyzed by Western blot as described above with the purified rabbit anti-His6-tagged VP26 IgG.

\section{Results and Discussion}

\section{Transcriptional Analysis of the DPV UL35 Gene in DPV-Infected Cells}

It is reported that the HSV-1 UL35 gene is a real late gene $\gamma 2$, and it is regulated by the presence of immediate early gene product and early gene product [47], but little is known about the transcription and expression kinetics of the DPV UL35 gene. To study the transcription kinetics of the DPV UL35 gene during the viral infection, RTPCR with SYBR Green I was conducted. The total RNA isolated from mock-infected and DPV-infected cells $24 \mathrm{~h}$ after infection was detected by $1.0 \%$ agarose gel electrophoresis (fig. 1a). The average relative content of DPV UL35 gene transcripts was calculated using the $2^{-\Delta \Delta C t}$ method and then logarithmized in order to observe the differences between various samplings. As shown in figure $1 \mathrm{~b}$, the DPV UL35 gene transcripts sharply rose first, then dropped slowly with the extension of the infection time. The transcripts of DPV UL35 gene could be detected as early as $0.5 \mathrm{~h}$ after infection, and then it increased 


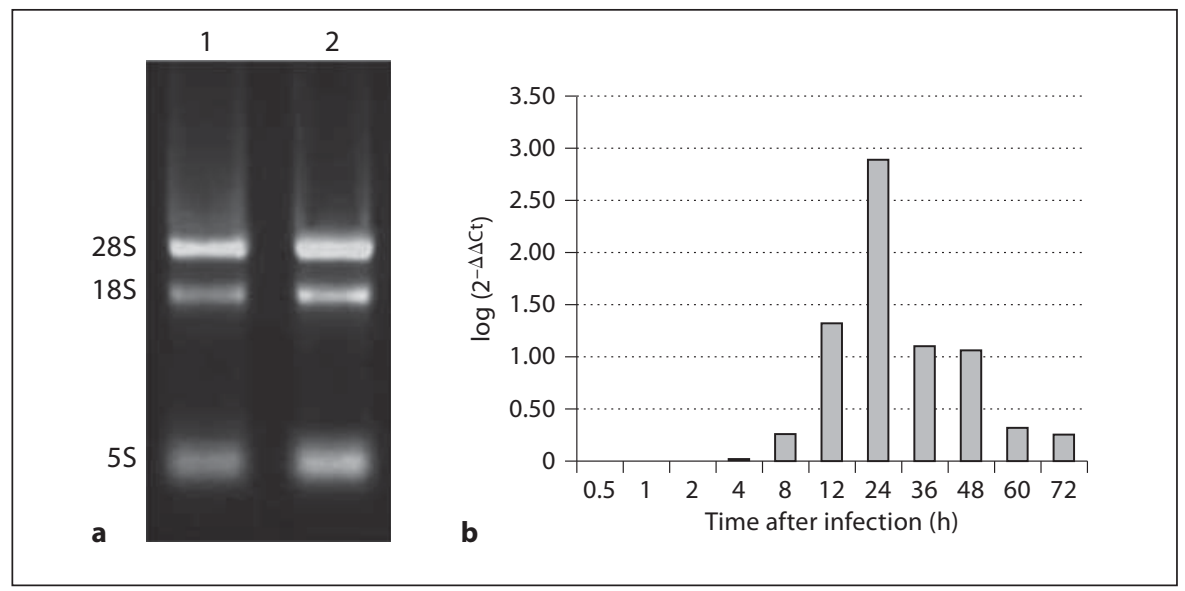

Fig. 1. a Agarose gel electrophoresis result of the total RNA. Lane 1 , total RNA isolated from mock-infected cells at $24 \mathrm{~h}$ after infection; lane 2, total RNA isolated from DPV-infected cells at $24 \mathrm{~h}$ after infection. b Transcriptional kinetic change of the DPV UL35 gene. The average relative content of the DPV UL35 gene transcripts was calculated at $0.5,1,2,4,8,12,24,36,48,60$ and $72 \mathrm{~h}$ after infection using the $2^{-\Delta \Delta C t}$ method and logarithmized for observing the differences between various samplings. The data were presented as the fold change in the DPV UL35 gene transcriptional expression normalized to a reference gene ( $\beta$-actin) and relative to the mock-infected control (negative control).

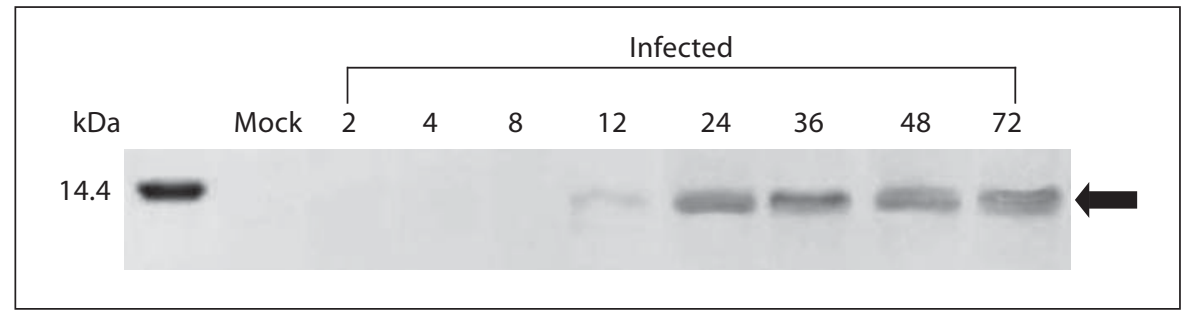

Fig. 2. Western blot analysis for the protein expression of the UL35 gene product in DPV-infected DEFs. DEFs were mock infected or DPV infected. The cells were harvested and lysed at 2, 4, $8,12,24,36,48$ and $72 \mathrm{~h}$ after infection. Proteins were separated by SDS-PAGE and subjected to Western blot analysis by using the

steadily and reached the peak at $12 \mathrm{~h}$ after infection, declining slowly thereafter to a certain degree at $24 \mathrm{~h}$ after infection, but maintained a relatively high level at $72 \mathrm{~h}$ after infection, which is the typical characterization of herpervirus late gene.

\section{Expressional Analysis of the DPV VP26 in DPV-Infected Cells}

Previous research [38] has shown that there is no signal polypeptide cleavage site in VP26 and the polypeptide chain of VP26 may contain a transmembrane domain. However, there are 9 potential phosphorylation sites in VP26, including 6 serine phosphorylation sites, 2 threonine phosphorylation sites and 1 tyrosine phos- rabbit anti-His6-tagged VP26 IgG. The hours after infection corresponding to each infected cell extraction are indicated above the lanes. The arrow shows the expected position for DPV VP26 (about $13 \mathrm{kDa}$ ). The protein molecular weight marker is shown on the left. phorylation site, which may be modified to a certain degree after translation and may play an on/off control role in the process of playing its biological functions, as well as acting as an important step for regulating the activity of enzyme or protein, since phosphorylation is a widely existing chemical modification after protein synthesis [48].

Here, the expression kinetics of VP26 in DPV-infected cells was analyzed by Western blot. At various times after infection, cell lysates were subjected to electrophoresis, transferred onto nitrocellulose membrane and reacted with the purified rabbit anti-His6-tagged VP26 IgG. As shown in figure 2, the antibodies were found to react strongly with a $13-\mathrm{kDa}$ protein produced in DPV-infect- 

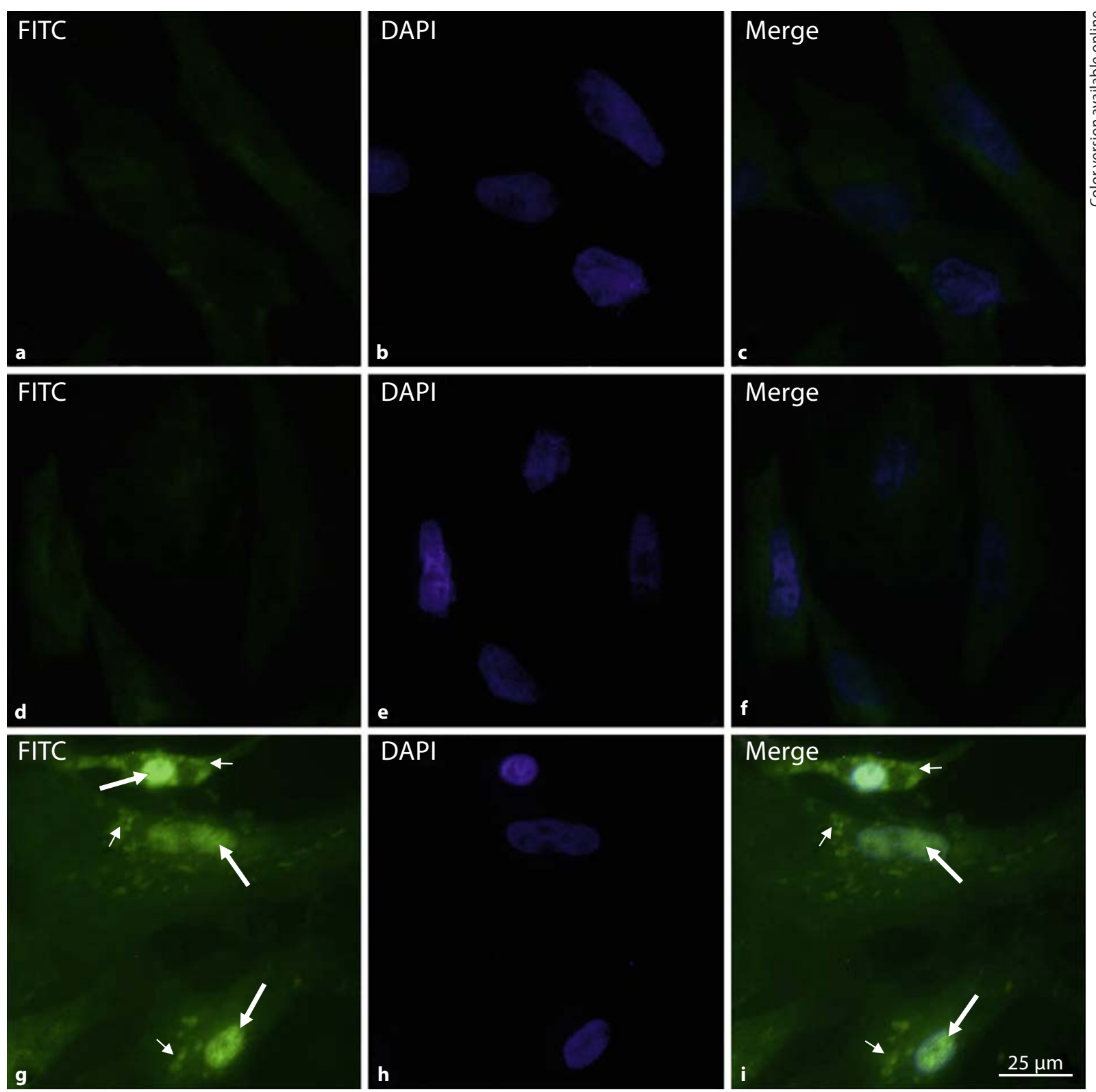

Fig. 3. Subcellular localization of the DPV VP26 analyzed by indirect immunofluorescence in DPV-infected cells. Mock-infected and DPV-infected cells were fixed with $4 \%$ paraformaldehyde at different stages $(2,4,8,12,24,48$ and $72 \mathrm{~h}$ after infecton) and incubated with purified rabbit anti-His6-tagged VP26 IgG, the cells were then stained with FITC-conjugated goat anti-rabbit IgG and DAPI as described in 'Materials and Methods'. Here, the figure only shows the subcellular localization of VP26 after DEFs had been infected by DPV at 24 h. a, d, g FITC staining. b, e, h DAPI staining. c, f, i Merged images of FITC and DAPI staining. Mockinfected cells were incubated with rabbit anti-His6-tagged VP26 IgG $(\mathbf{a}-\mathbf{c})$. DPV-infected cells were incubated with preimmune serum (d-f) or rabbit anti-His6-tagged VP26 IgG (g-i).

tion of the DPV VP26 occurred at the late stage of infection, indicating that the DPV UL35 protein is a late gene product, which may take part in the capsid assembly and the maturation of DPV virion. However, its precise role may depend on further research. 


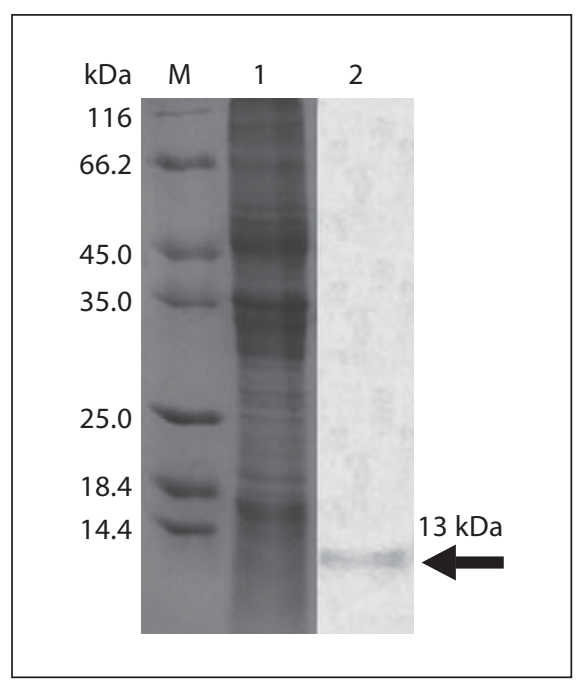

Fig. 4. The association of DPV VP26 with purified virions. Virions were collected and purified as described in 'Materials and Methods'. Purified virions were separated by SDS-PAGE, stained with Coomassie brilliant blue (lane 1 ) and then analyzed by Western blot with the rabbit anti-His6-tagged VP26 IgG (lane 2). Molecular mass marker sizes are shown on the left. The arrow indicates the DPV VP26.

\section{Subcellular Localization of the DPV VP26 in DPV-Infected Cells}

The location of encoded protein in cells is closely related to its functional execution. It is thought to be a universal phenomenon that almost every protein is marked with a correct location signal in the cell [49]. It is also believed that different intracellular localizations may reflect different functions of viral proteins, and the intracellular localizations of viral proteins may also vary at different times after infection. Moreover, homologous proteins may differ in intracellular localization in different herpesviruses. Previous subcellular localization prediction [38] has demonstrated that DPV VP26 mainly locates in nucleus (47.8\%) and functions as a nucleus-targeted protein. This result is consistent with $\mathrm{McNabb}$ and Courtney's [50] subcellular localization research, which suggests that HSV-1 VP26 mainly locates in the nucleus of HSV-1-infected cells and is strictly situated in a specific region of the nucleus, that is the punctate region.

In order to pinpoint the subcellular localization of the protein encoded by the DPV UL35 gene in DEFs at different stages, immunofluorescence experiments were carried out. At 2, 4, 8, 12, 24, 36, 48 and $72 \mathrm{~h}$ after infection, mock-infected and DPV-infected DEF cells were fixed and permeabilized as described in 'Materials and Methods'. Then, the cells were treated with BSA to block

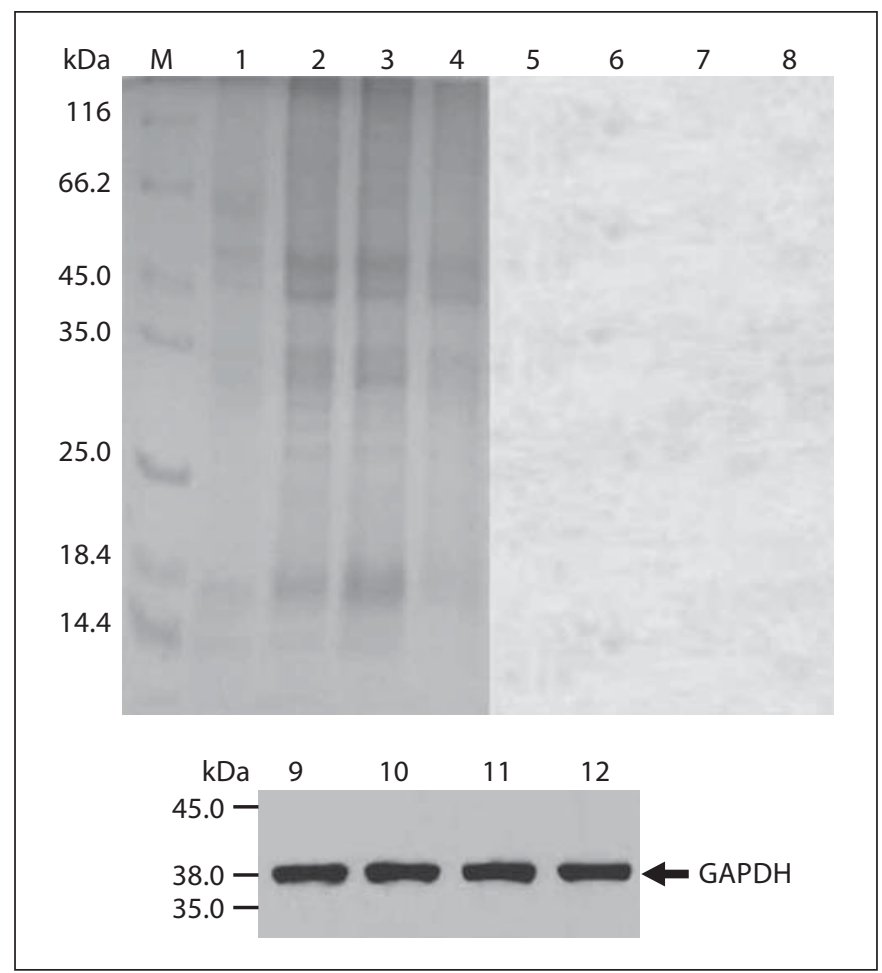

Fig. 5. The dependence of DPV UL35 protein production on viral DNA synthesis. The cells were cultured in the presence of $300 \mathrm{mg} /$ $\mathrm{ml} \mathrm{ACV}$ and harvested at 12 (lanes 1 and 5), 24 (lanes 2 and 6), 48 (lanes 3 and 7) and $72 \mathrm{~h}$ after infection (lanes 4 and 8). Proteins were separated by SDS-PAGE, stained with Coomassie brilliant blue (lanes 1-4) and analyzed by Western blot with the rabbit anti-His6-tagged VP26 IgG (lanes 5 and 8). Molecular mass marker sizes are shown on the left. Staining with mouse antiGAPDH (rabbit anti-glyceraldehyde-3-phosphate dehydrogease, Tiangen) antiserum at a dilution of 1:2,000, which corresponded to $12,24,48$ and $72 \mathrm{~h}$ after infection (lanes 9-12), was used as a loading control.

nonspecific binding and reacted with the purified rabbit anti-His6-tagged VP26 IgG. As illustrated in figure 3, infected cells (fig. 3g-i) showed a specific green fluorescent nuclear and/or cytoplasmic staining pattern. The specific fluorescence could be detected as early as $12 \mathrm{~h}$ after infection only in the cytoplasm of infected cells (fig. 3g, i, small arrow). Then, it increased gradually with the extension of infection at $24-48 \mathrm{~h}$ after infection and eventually reached the peak. At $24 \mathrm{~h}$ after infection, it transferred from the cytoplasm to the nucleus and aggregated in the punctate region of the nucleus (fig. 3g, i, large arrow). In contrast, no specific staining was observed in mock-infected cells that reacted with the rabbit antiHis6-tagged VP26 IgG (fig. 3a-c) or in DPV-infected cells reacted with preimmune serum (fig. $3 \mathrm{~d}-\mathrm{f}$ ). 
Interestingly, the homologous protein of DPV VP26, HSV VP26, exhibits a similar subcellular localization [50]. It is synthesized firstly in the cytoplasm of HSVinfected cells, then it locates in the nucleus and participates in assembly of capsid precursor [51], suggesting that the nuclear localization of DPV VP26 is closely related to its important function for the assembly and maturation of viral nucleocapsid.

\section{Association of DPV VP26 with Purified Virions}

The above results suggest that the VP26 protein may be a component of DPV virions. To determine this possibility, viruses from infectious supernatants obtained from the DPV-infected DEFs harvested at $48 \mathrm{~h}$ after infection were purified as described in 'Materials and Methods' and protein extracts were analyzed by Western blot. As shown in figure 4, the rabbit anti-His6-tagged VP26 IgG was found to react strongly with a $13-\mathrm{kDa}$ protein produced in DPV-infected cells (fig. 4, lane 2), suggesting that VP26 is a component of DPV virions.

\section{The Dependence of DPV VP26 on Viral DNA}

Synthesis

To determine whether the DPV VP26 protein is dependent on viral DNA synthesis, DEFs infected with DPV were maintained at various times $(12,24,48$ and $72 \mathrm{~h}$ after infection) after $1 \mathrm{~h}$ adsorption in the presence of ACV and analyzed by Western blot with the purified rabbit anti-His6-tagged VP26 IgG. DPV VP26 was not detectable in the presence of ACV, even at 48 and $72 \mathrm{~h}$ after infection (fig. 5, lanes 1-8), indicating that DPV VP26 protein synthesis was highly dependent on viral DNA synthesis. Since the expression of transcripts of the DPV VP26 are highly dependent on viral DNA synthesis, it can be concluded that DPV UL35 belongs to the $\gamma 2$ class of viral genes. This result correlates well with the HSV-1 UL35 gene [47].

Previous computer analysis [38] has shown that an apparently conserved domain can be found in DPV VP26, that is Herpes_UL35, a small nucleocapsid protein family. Accordingly, we can conclude that the DPV VP26 is a member of the small nucleocapsid protein family and has functions potentially related to its counterparts, which are encoded by the Herpes_UL35 genes. Meanwhile, studies of HSV-1 have documented that the UL35 protein (VP26), a small nucleocapsid protein encoded by the UL35 gene, is located on the hexon of the nucleocapsid. It is nonessential for the formation of the viral capsid and viral propagation in cell culture, however, it is important for viral replication production in the nervous system.
Furthermore, the absence of this protein will result in a 100 -fold reduced yield of infectious virus in the trigeminal ganglion $[47,52,53]$. This protein is located at the exterior of the icosahedral capsid, indicating that VP26 may serve as a core that connects the capsid with the external tegument and envelope in the late stage of viral assembly [52]. The sites of this protein that are exposed on the outside of the capsid also reveal that VP26 is in a favorable position to couple the capsid and its functional ligand, such as tegument [54]. Recent studies have also revealed that HSV-1 VP26 associates with ribosomes and may regulate the host cell translation [55]. Based upon the important role played by HSV-1 VP26 during HSV-1 infection, we suggest that DPV VP26 may have a similar function in the course of DPV infection. Importantly, the deletion of the UL35 gene in the research of DPV genetically engineering vaccine may become a new generation of vaccine. However, it is not yet known what the real biological functions of DPV VP26 in the herpesvirus life cycle are.

\section{Conclusion}

In this work, we presented the first identification of the DPV UL35 gene product as a $13-\mathrm{kDa}$ protein with the purified rabbit anti-His6-tagged VP26 IgG. The DPV VP26 was transcribed and expressed mainly at the late stage of infection, was highly dependent on viral DNA synthesis and was a component of extracellular mature virions. Thus, we suggest that the gene should be categorized as $\gamma 2$ class. In addition, immunofluorescence studies showed that VP26 firstly localized in the cytoplasm, then it transferred to the nucleus and aggregated in the punctate region of the nucleus in DPV-infected cells. Our report adds some new understanding to the biology of DPV infection. Further research involving the construction of the DPV UL35 gene mutant are required to study the functions of VP26 in the DPV life cycle.

\section{Acknowledgments}

The research was supported by grants from the National Natural Science Foundation of China (30771598), Changjiang Scholars and Innovative Research Team in University (PCSIRT0848), the earmarked fund for Modern Agroindustry Technology Research System (nycytx-45-12), the Scientific and Technological Innovation Major Project Funds in University (706050), the Cultivation Fund of the Key Scientific and Technical Innovation Project, Department of Education of Sichuan Province (07ZZ028), the Sichuan Province Basic Research Program (07JY029-016/17). 


\section{References}

$\checkmark 1$ Toth TE: Active immunization of white Pekin ducks against duck virus enteritis duck plague with modified 371 live virus vaccines immunization of ducklings. Am J Vet Res 1970;31:1275-1279.

$\checkmark 2$ Proctor SJ: Pathogenesis of duck plague in the bursa of Fabricius, thymus, and spleen. Am J Vet Res 1976;37:427-431.

$\checkmark 3$ Rajan A, Nair MK, Maryamma KI, Valsala KV: Studies on the epidemiology symptoms and pathoanatomy of duck plague infection duck viral enteritis. Indian Vet J 1980;57:1215.

$\checkmark 4$ Das NP, Dewan ML, Baki MA, Das PM, Sarker AJ: Pathology of experimental duck plague in Bangladesh. Indian Vet J 1990;67: 197-202.

5 Marlier D, Jaumin F, Delleur V, Sturbois M, Vindevogel H: Duck plague: a permanent threat for domestic and wild anatids. Ann Med Vet 2001;145:287-291.

6 Malmarugan S, Sulochana S: Detection of duck plague viral antigen in tissues by immunoperoxidase test. Indian Vet J 2002;79: 103-105.

7 Baudet AERF: Mortality in ducks in the Netherlands caused by a filtrable virus: fowl plague. Tijdschr Diergeneesk 1923;50:455459.

$\checkmark 8$ Leibovitz L, Hwang J: Duck plague on the American continent. Avian Dis 1968;12:361378.

9 Jansen J, Kunst H: The reported incidence of duck plague in Europe and Asia. Tijdschr Diergeneesk 1964;89:765-769.

10 Lucam F: La peste aviaire en France. Repoc 14th Int Vet Congr 1949;2:380-382.

11 Sandhu TS, Shawky SA: Duck Virus Enteritis (Duck Plague), ed 11, rev. Iowa, Iowa State University Press, 2003, pp 354-363.

12 Fauquet CM, Mayo MA, Maniloff J, Desselberger U, Ball LA: Virus Taxonomy: Eighth Report of the International Committee on Taxonomy of Viruses. San Diego, Elsevier Academic Press, 2005.

$\checkmark 13$ Kaleta EF: Herpesviruses of birds - a review. Avian Pathol 1990;19:193-211.

14 Shawky S, Schat KA: Latency sites and reactivation of duck enteritis virus. Avian Dis 2002;46:308-313.

15 Burgess EC, Ossa J, Yuill TM: Duck plague: a carrier state in waterfowl. Avian Dis 1979; 23:940-949.

-16 Plummer PJ, Alefantis T, Kaplan S, O’Connell P, Shawky S, Schat KA: Detection of duck enteritis virus by polymerase chain reaction. Avian Dis 1998;42:554-564.

-17 Chi JH, Wilson DW: ATP-dependent localization of the herpes simplex virus capsid protein VP26 to sites of procapsid maturation. J Virol 2000;74:1468-1476.

- 18 Pan H, Cao R, Liu L, Niu M, Zhou B, Chen P, $\mathrm{Hu} \mathrm{J}$ : Molecular cloning and sequence analysis of the duck enteritis virus UL5 gene. Virus Res 2008;136:152-156.
19 Chen S, Han Z, Shao Y, Liu S, Kong X: Molecular characterization of UL6 gene of duck enteritis virus. Chin J Virol 2006;22:391396.

20 Han XJ, Wang JW, Ma B: Cloning and sequence of glycoprotein $\mathrm{H}$ gene of duck plague virus. Agric Sci China 2006;5:397-402.

21 Li H, Liu S, Kong X: Characterization of the genes encoding UL24, TK and $\mathrm{gH}$ proteins from duck enteritis virus (DEV): a proof for the classification of DEV. Virus Genes 2006; 33:221-227.

22 Jia R, Cheng A, Wang M, Xin H, Guo Y, Zhu D, Qi X, Zhao L, Ge H, Chen X: Analysis of synonymous codon usage in the UL24 gene of duck enteritis virus. Virus Genes 2009;38 96-103.

23 Liu SW, Chen SH, Li HX, Kong XG: Molecular characterization of the herpes simplex virus 1 (HSV-1) homologues, UL25 to UL30, in duck enteritis virus (DEV). Gene 2007;401: 88-96.

24 An R, Li H, Han Z, Shao Y, Liu S, Kong X: The ul31 to ul35 gene sequences of duck enteritis virus correspond to their homologs in herpes simplex virus 1. Acta Virol 2008;52:23-30.

25 Cai MS, Cheng AC, Wang MS, Zhao LC, Zhu DK, Luo QH, Liu F, Chen XY: His6-tagged UL35 protein of duck plague virus expression, purification, and production of polyclonal antibody. Intervirology 2009;52:141151.

26 Xie W, Cheng A, Wang M, Chang H, Zhu D, Luo Q, Jia R, Chen X: Expression and characterization of the UL31 protein from duck enteritis virus. Virol J 2009;6:19.

27 Xie W, Cheng AC, Wang MS, Chang H, Zhu DK, Luo QH: Molecular cloning and characterization of the UL31 gene from duck enteritis virus. Mol Biol Rep 2010;37:14951503.

28 Liu FY, Ma B, Zhao Y, Zhang Y, Wu YH, Liu XM, Wang JW: Characterization of the gene encoding glycoprotein $\mathrm{C}$ of duck enteritis virus. Virus Genes 2008;37:328-332.

29 Xu C, Li XR, Xin HY, Lian B, Cheng AC, Wang MS, Zhu DK, Jia RY, Luo QH, Chen $\mathrm{XY}$ : Cloning and molecular characterization of gC gene of duck plague virus. Chin Vet Sci 2008;38:1038-1044.

30 Zhao LC, Cheng AC, Wang MS, Yuan GP, Jia RY, Zhou DC, Qi XF, Ge H, Sun T: Identification and characterization of duck enteritis virus dUTPase gene. Avian Dis 2008;52:324331.

-31 Shen CJ, Cheng AC, Wang MS, Guo YF, Zhao LC, Wen M, Xie W, Xin HY, Zhu DK: Identification and characterization of the duck enteritis virus UL51 gene. Arch Virol 2009; 154:1061-1069.

-32 Zhao LC, Cheng AC, Wang MS, Yuan GP, Cai MS: Characterization of codon usage bias in the dUTPase gene of duck enteritis virus. Prog Nat Sci 2008;18:1069-1076.
33 Zhao Y, Wang JW, Ma B, Liu F: Molecular analysis of duck enteritis virus US3, US4, and US5 gene. Virus Genes 2009;38:289-294.

$>34$ Xin HY, Cheng AC, Wang MS, Jia RY, Shen CJ, Chang H: Identification and characterization of a duck enteritis virus US3-like gene. Avian Dis 2009;53:363-369.

35 Chang H, Cheng AC, Wang MS, Guo YF, Xie W, Lou KP: Complete nucleotide sequence of the duck plague virus gE. Arch Virol 2009; 154:163-165

36 Zhao Y, Wang JW, Liu F, Ma B: Molecular analysis of US10, S3, and US2 in duck enteritis virus. Virus Genes 2009;38:243-248.

>37 Cheng AC, Wang MS, Wen M, Zhou WG, Guo YF, Jia RY, Xu C, Yuan GP, Liu YC: Construction of duck enteritis virus gene libraries and discovery, cloning and identification of viral nucleocapsid protein gene. High Technology Lett 2006;16:948-953.

38 Cai MS, Cheng AC, Wang MS, Zhu DK, Luo $\mathrm{QH}$, Zhao LC, Chen XY: Cloning and molecular characterization of VP26 gene of duck plague virus. Acta Vet Zootechnica Sin 2009;40:1112-1119.

39 Li BW, Rush AC, Tan J, Weil GJ: Quantitative analysis of gender-regulated transcripts in the filarial nematode Brugia malayi by realtime RT-PCR. Mol Biochem Parasitol 2004; 137:329-337.

40 Livak KJ, Schmittgen TD: Analysis of relative gene expression data using real-time quantitative PCR and the $2^{-\Delta \Delta C T}$ method. Methods 2001;25:402-408.

41 Towbin H, Staehelin T, Gordin J: Electrophoretic transfer of proteins from polyacrylamide gels to nitrocellulose sheets: procedure and some applications. Proc Natl Acad Sci USA 1979;76:4350-4354.

42 Haimovich B, Aneskievich BJ, Boettiger D: Cellular partitioning of $\beta-1$ integrins and their phosphorylated forms is altered after transformation by Rous sarcoma virus or treatment with cytochalasin D. Cell Regul 1991;2:271-283.

43 Miller WJ, Skinner JA, Foss GS, Davies KE: Localization of the fragile $\mathrm{X}$ mental retardation 2 (FMR2) protein in mammalian brain. Eur J Neurosci 2000;12:381-384.

44 Farina A, Feederle R, Raffa S, Gonnella R, Santarelli R, Frati L, Angeloni A, Torrisi MR, Faggioni A, Delecluse HJ: BFRF1 of EpsteinBarr virus is essential for efficient primary viral envelopment and egress. J Virol 2005; 79:3703-3712.

45 Guo YF, Cheng AC, Wang MS, Zhou Y: Purification of anatid herpesvirus 1 particles by tangential-flow ultrafiltration and sucrose gradient ultracentrifugation. J Virol Methods DOI: 10.1016/j.jviromet.2008.12.017.

46 Wada K, Goshima F, Takakuwa H, Yamada H, Daikoku T, Nishiyama Y: Identification and characterization of the UL14 gene product of herpes simplex virus type 2. J Gen Virol 1999;80:2423-2431. 
-47 McNabb DS, Courtney RJ: Identification and characterization of the herpes simplex virus type 1 virion protein encoded by the UL35 open reading frame. J Virol 1992;66: 2653-2663.

-48 Kishimoto A, Nishiyama K, Nakanishi H, Uratsuji Y, Nomura H, Takeyama Y, Nishizuka Y: Studies on the phosphorylation of myelin basic protein by protein kinase $\mathrm{C}$ and adenosine $3^{\prime}: 5^{\prime}$-monophosphate-dependent protein kinase. J Biol Chem 1985;260:1249212499.

49 Feng ZP: An overview on predicting the subcellular location of a protein. In Silico Biol 2002;2:291-303.

50 McNabb DS, Courtney RJ: Posttranslational modification and subcellular localization of the p12 capsid protein of herpes simplex virus type 1. J Virol 1992;66:4839-4847.
51 Newcomb WN, Homa FL, Thomsen DR, Trus BL, Cheng N, Steven A, Booy F, Brown JC: Assembly of the herpes simplex virus procapsid from purified components and identification of small complexes containing the major capsid and scaffolding proteins. J Virol 1999;73:4239-4250.

52 Booy FP, Trus BL, Newcomb WW, Brown JC, Conway JF, Steven AC: Finding a needle in a haystack: detection of a small protein (the $12-\mathrm{kDa}$ VP26) in a large complex (the $200-$ MDa capsid of herpes simplex virus). Proc Natl Acad Sci USA 1994;91:5652-5656.
53 Desai P, DeLuca NA, Person S: Herpes simplex virus type 1 VP26 is not essential for replication in cell culture but influences production of infectious virus in the nervous system of infected mice. Virology 1998;247: 115-124.

54 Booy FP, Trus BL, Davison AJ, Steven AC: The capsid architecture of channel catfish virus, an evolutionarily distant herpesvirus, is largely conserved in the absence of discernible sequence homology with herpes simplex virus. Virology 1996;215:134-141.

55 Greco A, Bienvenut W, Sanchez JC, Kindbeiter K, Hochstrasser D, Madjar JJ, Diaz JJ: Identification of ribosome-associated viral and cellular basic proteins during the course of infection with herpes simplex virus type 1 . Proteomics 2001;1:545-549. 